\title{
Research on Legal Compliance in the Application of Government Big Data
}

\author{
Dingzhuang Chen \\ Xiamen Huaxia University \\ Xiamen, China 361016
}

\author{
Xiaokun Jiang \\ Tenet \& Partners \\ Xiamen, China 361006
}

\begin{abstract}
In order to solve the "information island" problem in the process of government affairs informatization, the Chinese government has vigorously carried out the integration of government affairs information resources and achieved certain results. However, government affairs information resources still have problems such as unknown sources, irregular information arrangement, unclear sharing definition, and overly rough open design. Doing a good job of internal data risk control compliance, standardizing the qualification approval of outsourcing organizations, and formulating standards and policies for government data will help achieve legal compliance for government data integration.
\end{abstract}

Keywords-government affairs information resources; government affairs data integration; data compliance

\section{INTRODUCTION}

With the advent of the information age, in order to reform traditional government management and public services, the government initiated major informatization application projects in the 1990s and held a national informatization work conference. At the same time, the 16th National Congress of the Communist Party of China has made strategic plans to promote industrialization with informatization, promote informatization with industrialization, and take a new path of industrialization. The Fifth Plenary Session of the 16th CPC Central Committee further emphasized the promotion of national economic and social informatization and accelerated transformation of economic growth. ${ }^{1}$

In the early 21st century, the government's informatization development strategy achieved initial results, and major government departments' websites were set up one after another; but at the same time, there is a problem of "separate politics and separate divisions" among various departments. There are "information silo" and "information islands", and it is difficult to get through government affairs information. The depth development of government informatization has encountered difficulties.

\section{INTEGRATED DEVELOPMENT OF GOVERNMENT INFORMATION RESOURCES}

In order to solve the problem of "individual government" of government information, under the deployment of the Party Central Committee in 2015, the State Council issued the "Outline of Action for Promoting the Development of Big Data". The document explicitly mentioned the need to promote the integration of government data, including data sharing and openness. From now on, the integration of government big data is accelerated. The integration of government information resources is mainly carried out from three aspects, namely: publishing document regulations, and trying to build a system of data integration, improving infrastructure construction and support data integration and development, promoting the integration of government information resources and sharing open data resources. So far, the integration of government information resources has achieved some results.

\section{A. Following the Mechanism, the Top-level Design Takes Effect}

The State Council issued the Outline of Action for the Promotion of Big Data in 2015. Approved by the State Council on February 4, 2016, the National Development and Reform Commission, the Ministry of Industry and Information Technology and other departments led the establishment of the "Big Data Development InterMinisterial Liaison Conference". The "Inter-Ministerial Liaison Conference" serves as a hub and bridge between various departments. Through several meetings, it issued documents such as the Interim Measures for the Administration of Government Information Resources Sharing and the Guidelines for the Cataloging of Government Information Resources (for Trial Implementation), further promoting the integration of government data. So far, through the consolidation of consensus by the system, government departments have figured out a method of compiling a catalog of government information resources, and have a clear understanding of the sharing of government data, the division of responsibilities, and the establishment of institutions. ${ }^{2}$

\footnotetext{
See the "Guidelines for Compiling Government Information Resources Catalogue (Trial)”.
} 
development ministerial contact meeting" platform. Finally, the results of the compromises of various departments were fixed through regulatory documents, and transmitted through the administrative forces, and finally the integration of data was completed. The process of the state using administrative power to promote data integration is shown in "Fig. 1": government affairs data on the same platform for discussion, game, and negotiation with the help of "big data

"Three-year plan for promoting the development of big data (2016-2018)"

Key points for promoting big data development in 2016

"Guidelines for the cataloging of government information resources (trial)"

\begin{abstract}
Platform for Action to Promote Big Data

Inter-ministerial association for the development of big data

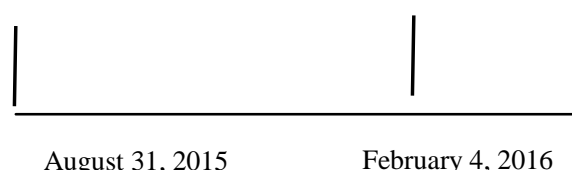

August 31, 2015

Fig. 1. Diagram of the process of data integration.

\section{B. Technical Support, Infrastructure Is Beginning to Take Shape}

"Interim measures for government affairs information resource sharing management"
Implementation plan for integration and sharing of government affairs information system

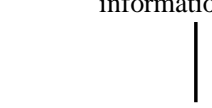

June 2, 2017

In addition to the system first, the government has also invested a lot of manpower and material resources in the construction of basic hardware facilities. The "Thirteenth Five-Year Plan" National Government Informatization Engineering Construction Plan clearly states that it is necessary to build a comprehensive public infrastructure platform in accordance with the "digital, cloud, network, and terminal" integration and innovation trend and the demand for intensive e-government construction. At the same time, it is necessary to build a unified national data sharing exchange hub and fully penetrate provincial data sharing exchange hub nodes. 3 As of now, the government has established the national e-government intranet and extranet, and has achieved multi-level coverage of government departments at the central, provincial, city and county levels.

In terms of technical support, the government's approach is mainly to build basic hardware facilities in accordance with government data sharing and open thinking. An integrated government affairs data platform, the government affairs extranet and intranet, and the multi-link and multinode interconnection of the intranet and extranet are constructed to achieve unimpeded data, multi-level circulation, sharing at various points, and orderly opening.

Refer to Chapter 3 "Main Tasks" in the "Thirteenth Five-Year Plan" National Government Informationization Project Construction Plan.

\section{Data Integration, Sharing and Opening of Government Affairs Platform}

In the final analysis, the government's system implementation and infrastructure construction is to achieve data integration. In terms of data integration, the government uses the government affairs cloud to build a unified national government data center. Through the extraction and compilation of initial data, the collection and classification of government information resource catalogs, the center classifies the reasonably arranged data into the population basic information base, legal entity basic information base, natural resources and geospatial basic information base, etc., and then stores it in the National Government Data Center. So far, the national government data center has begun to shape, and the data at the central, provincial, city, and county levels have begun to be gradually imported into the data center.

In terms of data integration, the government's approach is to form a government affairs database through the orderly compilation and aggregation of government affairs data. When necessary, government departments at all levels can directly share relevant data in the database through applications. When the government's open website needs it, it directly proposes that it does not involve confidential information and opens it to the outside world. In the end, the entire government data system will be operated efficiently and orderly.

\section{LEGAL ISSUES IN THE INTEGRATED DEVELOPMENT OF GOVERNMENT INFORMATION RESOURCES}

The integration of government information resources has achieved certain results so far. It is the integration of data 
through the construction of hardware facilities and the implementation of systems, in accordance with a set of standardized processes.
National government

affairs data center (storage)
National e-government

intranet (sharing)

National e-government extranet (opening)

Fig. 2. Standard flowchart of government information resource integration.

The specific process is as follows: First, government departments at all levels collect government affairs information resources, extract metadata from the collected government affairs information resources, and make them datamation. ${ }^{4}$ Second, put the data information into various government information resource directories. For example, "name" is put into the population basic information base by way of number 01, and "Yangtze River" is put into the geospatial basic information base by way of number 02 . ${ }^{5}$ Then, the government information resource catalog is stored uniformly in the national government data center. Finally, if necessary, departments and agencies at all levels can apply to share government affairs data. If citizens need to inquire, the government data center may open non-confidential information for inquiry. The overall process is shown in "Fig. $2 "$.

However, after research and analysis, the author finds that the integration of government data has legal problems in many aspects, such as data source, organization, sharing, and openness.

\section{A. The Source of the Data Is Illegal, and the Poisonous Fruits of the Data Are Secretly Hidden}

Regarding the source of the data, the Interim Measures for the Administration of Government Affairs Information Resource Sharing stipulates that government affairs data can be collected directly by government departments or collected by third parties in accordance with law. ${ }^{6}$ In fact, because the

4 See the "Guidelines for Compiling Government Information Resources Catalogue (Trial)". The specific approach is to make government affairs information resources. For example, just as the 18 digits on the ID card represent personal information, the multiple digits of the government affairs information resource represent a certain type of government affairs information.

The numbers 01 and 02 are only for the convenience of display, not the formal numbering mode in practical operation.

6 Article 2 of the "Interim Measures for the Management of Government Information Resources Sharing" states: "The government information resources referred to in these measures refer to documents, materials, charts and records produced or obtained by government departments in the course of performing their duties in a certain form, various types of information resources such as data. It includes information resources collected directly or through a third party in accordance with the

data collected directly by the government has public power, it is inherently reasonable. However, how to ensure the cleanliness of data sources and how to evaluate the legitimacy of data sources through data collected by third parties?

It should be noted that since the State Council issued the "Outline of Action to Promote the Development of Big Data" in 2015, the integration of government data has only developed for a short time. In the implementation of the system, it pays more attention to how to coordinate the conflicts of interest of various departments to implement the integration of government data. As for how to legally collect data through third parties, no special regulatory documents have been issued. In other words, there is no legal provision for third-party collection of government data. In the unregulated areas of the government, gray spaces will breed. Perhaps deterred by public authority or greed for data's property value, third parties will inevitably have problems collecting data illegally when collecting data. Because the above-mentioned view is not supported by real data, the argument is unavoidable. ${ }^{7}$ The author will use the credit reporting agency as an example to reversely demonstrate the above view.

As everyone knows, the responsibility of credit reporting agencies is to collect user credit data. The establishment of a personal credit reporting agency must be approved by the People's Bank of China and it must have the corresponding qualifications. At the same time, relevant information of

law, authorized by the law, and formed based on the government information system for the performance of duties. "

7 User data collected by credit reporting agencies can be used as a reference for government departments to make decisions. The state has issued a series of documents to regulate credit reporting agencies. For example, "Regulations on the Administration of Credit Investigation Industry", "Measures for the Administration of Credit Investigation Agencies", "Guidelines on Supervision of Credit Reference Agencies", and so on. However, because the regulatory documents are limited to the normative field of credit information, they are not files that specifically regulate the collection of user data by third parties. Therefore, the author believes that up to now, China has not issued any special regulatory documents to regulate third parties to legally collect user data. 
third-party agencies for processing. ${ }^{13}$ At the same time, due to the high technical barriers in the construction of the government affairs cloud, many government departments cannot complete it independently and often outsource it to third-party technical institutions for processing. ${ }^{14}$ Among them, the outsourcing of data, especially the overall outsourcing of the infrastructure that carries the data, has a great risk of data leakage.

In the maintenance and update of government affairs information resources, after searching, the author found that many institutions have not realized the importance of data, did not implement the requirements of the network security level protection system, did not record data, and did not set data security responsibility people. There are many shortcomings in data security protection, which can easily lead to data leakage. "Table I" shows the cases where data specifications are not in place: supervision, there is still illegal behavior in collecting user data by third parties, not to mention unsupervised areas. Once the third party collects information and data with insufficient cleanliness and illegally collected information, such data may become a poisonous fruit of data, causing unimaginable harm to the later use, sharing and opening of data.

\section{B. Data Is Not Standardized, and There Are Risks of Data Leakage}

In terms of data collation, the "Interim Measures for the Management of Government Information Resources Sharing" stipulates that all government departments should compile, maintain, and update departmental government information resource catalogs as required. ${ }^{9}$ It is learned that the classification of government information resource catalogs includes resource attribute classification, secretrelated attribute classification, shared attribute classification, and hierarchical attribute classification. Each classification also needs to be classified into corresponding small items. ${ }^{10}$ At the same time, according to the People's Republic of China Network Security Law, network operators should formulate network security management systems and operating procedures in accordance with the requirements of the network security level protection system, implement data classification, backup and encryption of important data, etc. ${ }^{11}$ At the same time, after the government affairs information resource catalog and other data are sorted out, they need to be uploaded to the government affairs cloud platform. ${ }^{12}$

It can be seen from the above that the compilation of the government information resource catalog takes a long time, has a large amount of engineering, and requires more manpower. Government departments with limited administrative resources often outsource data to external

8 See the provisions of the "Measures for the Administration of Credit Bureaus"

9 See Article 8 of the Interim Measures for the Management of Government Information Resources Sharing.

${ }_{10}$ See the "Guidelines for Compiling Government Information Resources Catalogue (Trial)"

11 See Article 21 of the People's Republic of China Network Security Law

12 See the "Thirteenth Five-Year" National Government Informationization Project Construction Plan.

13 For example, the data of Guangzhou 12345 government service hotline is outsourced to a third data agency for processing, see: China Government Procurement Network: http://www.ccgp.gov.cn/cggg/dfgg/gkzb/201905/t20190515_12079830.htm. Last visit: October 28, 2019.

14 For example, Jinhua E-Government Center Jinhua Municipal Affairs Cloud Resources Big Data Service Outsourcing Project singlesource procurement announcement. See: China Government Procurement Network:

http://www.ccgp.gov.cn/cggg/dfgg/dylygg/201512/t20151217_6353663.ht m. Last visit: October 28, 2019;

15 Inner Mongolia Autonomous Region Economic Informatization Commission, the announcement of the successful bidding (transaction) of this level of Inner Mongolia Autonomous Region e-government external network cloud center outsourcing service project, see: China Government Procurement Website: http://www.ccgp.gov.cn/cggg/dfgg/zbgg/201710/t20171023_9030164.htm. Last visit: October 28, 2019 
TABLE I. CASES OF Violations OF DATA SECURity

\begin{tabular}{|c|c|c|c|}
\hline Object of Punishment & Law Enforcement Authorities & Inspection / Irregularities & Punitive Measures \\
\hline $\begin{array}{l}\text { A staff of a community } \\
\text { service center }\end{array}$ & $\begin{array}{lll}\text { Wangcang } & \text { County } & \text { Public } \\
\text { Security Bureau Cyber } & \text { Police } \\
\text { Brigade } & & \\
\end{array}$ & $\begin{array}{l}\text { Using the intranet of the service } \\
\text { department to illegally obtain } \\
\text { personal information }\end{array}$ & Bringing to justice \\
\hline A provincial institutions & $\begin{array}{l}\text { Network police of a city and } \\
\text { county level public security } \\
\text { organ }\end{array}$ & $\begin{array}{l}\text { Failure to take measures such as } \\
\text { internal security management } \\
\text { systems and operating procedures } \\
\text { in accordance with the provisions } \\
\text { of the Cyber Security Law }\end{array}$ & $\begin{array}{l}\text { Warning and order for } \\
\text { correction }\end{array}$ \\
\hline $\begin{array}{l}\text { Huainan Vocational } \\
\text { Technical College }\end{array}$ & $\begin{array}{l}\text { Internet Police Detachment of } \\
\text { Huainan Public Security Bureau }\end{array}$ & $\begin{array}{l}\text { Network security management } \\
\text { system has not been } \\
\text { implemented, network security } \\
\text { protection measures have not } \\
\text { been established, and the } \\
\text { retention of network diaries is } \\
\text { less than } 6 \text { months }\end{array}$ & $\begin{array}{l}\text { Warning and order for } \\
\text { correction }\end{array}$ \\
\hline A institution & $\begin{array}{l}\text { Network police of a public } \\
\text { security organ }\end{array}$ & $\begin{array}{l}\text { Network security management } \\
\text { system has not been } \\
\text { implemented, network security } \\
\text { protection measures have not } \\
\text { been established, and the } \\
\text { retention of network diaries is } \\
\text { less than } 6 \text { months }\end{array}$ & Fine \\
\hline
\end{tabular}

It can be seen that due to the lack of awareness of data protection, the government affairs department has outstanding problems such as insufficient data protection and data leakage in the preparation, maintenance, and update of government affairs information resources.

\section{Unclear Data Sharing, Data Islands Are Difficult to Break}

According to the type of sharing, government affairs information resources are divided into three types: unconditional sharing, conditional sharing, and no sharing. ${ }^{15}$ Among them, the information resources that are unconditional sharing can be directly obtained by the using department; the information departments that are conditional sharing must apply for the using department; the information resources that are no sharing must be explained by the providing department. ${ }^{16}$

The types of government information resources seem to be clearly classified. However, after careful consideration, it will be found that the division has not played a practical role. Because the three types of conceptual definitions are uncertain legal concepts. The law does not clearly define which information resources can be shared unconditionally, which can be shared conditionally, and which are not shared. Further analysis, in terms of the type of no sharing, the "Interim Measures for the Administration of Government Information Resource Sharing" stipulates that as long as the reason provided by the department, it may not be shared. In practice, there are often cases where the administrative department is unwilling to share or dare not share. In this case, if the initiative to not share information resources is

16 See Article 9 of the Interim Measures for the Management of Government Information Resources Sharing.

17 See Article 12 of the Interim Measures for the Management of Government Information Resources Sharing. given to the providing department, the integration of information resources will be hindered, and the "information island" problem cannot be solved completely as usual.

In order to verify the author's point of view, the author compared the problems of insufficient data openness in the "National Government Service Platform" APP, Fujian "Minzhengtong" APP and Xiamen "i Xiamen" APP. ${ }^{17}$ After comparison, the author found that the government affairs data on Fujian's "Minzhengtong" was not fully open to the "National Government Service Platform". The government affairs data on "i Xiamen" 18 are not all available to "Minzhengtong" in Fujian Province. ${ }^{19}$ That is, not all government data of the central government, provinces, cities and prefectures are open to communication.

The author believes that the biggest problem with the open sharing of government affairs information resources is that the legislature has not yet clarified which government

18 Because government affairs information resource sharing requires permission to enter the administrative agency for investigation, subject to practical factors, government information resource sharing cannot be investigated. However, due to the commonality of government affairs information resources in opening and sharing, the author attempts to verify the opacity of government information resources in sharing and opening up through comparative research on the openness of government information resources

19 Specifically, the "government affairs service platform" on Fujian government affairs data only has two types: "medical health" and "other" However, on the "Minzhengtong" service platform, Fujian Province's government affairs data includes various categories such as "Typhoon Path", "Provident Fund Query", "ETC Appointment Processing", "Medical Insurance QR Code Purchase", "Social Security Query" and other categories.

20 Specifically, the "Minzhengtong" service platform in Fujian Province has only a column for "authentication of fiscal bills" for "tax payment". The "i-Xiamen" service platform of Xiamen City has various categories such as "Xiamen Tax", "Waiting for Taxes", "Tax Bookings", and "Non-tax Bill Verification". 
affairs data can be shared openly and which government affairs data cannot be shared openly. The most essential reason is that the data providing department itself is afraid of sharing and unwilling to share data because of its interests and fear of responsibility.

\section{Data Opening Is Not Cautious, and Data Crawling Problems Are Prominent}

In April 2019, the State Council issued the Regulations on the Disclosure of Government Information. The Administrative Regulations formally established the principle that "openness is the norm, and non-disclosure is the exception" in the disclosure of government information by administrative agencies. ${ }^{20}$ At the same time, it revised the old regulations that citizens, legal persons or other organizations can only apply for information disclosure due to "special needs such as their own production, living, and scientific research, stipulated that citizens, legal persons or other organizations can directly apply for information disclosure. ${ }^{21}$ It can be seen that the new "Regulations on the Disclosure of Government Information" has expanded the depth and breadth of government information disclosure and is conducive to the transparency and fairness of government information.

But at the same time, the author is also deeply concerned about the expansion of government information. As we all know, during the old "Government Information Disclosure Regulations", the government information disclosure network often suffered the leakage of citizen information. The release of the new "Government Information Disclosure Regulations" has further expanded the scope of government information disclosure, but at the same time has increased the risk of personal information leakage. How to effectively balance the conflict between government information disclosure and personal privacy is a question worth pondering. The following "Table II" retrieves the cases of government information leakage:
TABLE II. LIST OF GOVERNMENT INFORMATION DISCLOSURE CASES

\begin{tabular}{|c|c|}
\hline Government & Information Disclosure Behavior \\
\hline $\begin{array}{l}\text { Tongling } \\
\text { Municipal } \\
\text { Government } \\
\text { Information } \\
\text { Disclosure } \\
\text { Website }\end{array}$ & $\begin{array}{l}\text { The "Sunshine Community } 2017 \text { Pre- } \\
\text { pregnancy Eugenics Health Checklist" (index } \\
\text { number 080313743 / 201708-00058) } \\
\text { announced the names and dates of } 40 \text { couples, } \\
\text { of which the ID numbers of } 77 \text { people are } \\
\text { completely presented, and the list only } \\
\text { obscures the address of the current residence. }\end{array}$ \\
\hline $\begin{array}{l}\text { Hefei } \\
\text { Municipal } \\
\text { Government } \\
\text { Information } \\
\text { Disclosure } \\
\text { Website }\end{array}$ & $\begin{array}{l}\text { The "Roster of Medical Aid Objects in Xinglin } \\
\text { Street, Luyang District (January to October)" } \\
\text { (index: 77499343X / 201710-00017) disclosed } \\
\text { personal information such as residential } \\
\text { address and contact phone number. In } \\
\text { addition, the condition of these people can also } \\
\text { be viewed, including uremia, lung cancer, } \\
\text { chronic renal failure, and so on. }\end{array}$ \\
\hline $\begin{array}{l}\text { Jingdezhen } \\
\text { Municipal } \\
\text { Government } \\
\text { Information } \\
\text { Disclosure } \\
\text { Website } \\
\end{array}$ & $\begin{array}{l}\text { The "Second Batch of College Students' One- } \\
\text { off Business Subsidy Public Notice" } \\
\text { (Information Request Number: H00140-0403- } \\
\text { 2017-0077) announced the student's name, } \\
\text { complete ID number, and contact phone } \\
\text { number. }\end{array}$ \\
\hline $\begin{array}{l}\text { Yichun } \\
\text { Municipal } \\
\text { Government } \\
\text { Information } \\
\text { Disclosure } \\
\text { Website }\end{array}$ & $\begin{array}{l}\text { The "Announcement on the Publication of the } \\
\text { List of Qualified Personnel in the Yichun } \\
\text { Examination Area of the Paperless } \\
\text { Examination for the Primary Qualification of } \\
\text { Accounting in 2017" (Information Request } \\
\text { Number: C00120-0403-2017-0005) includes } \\
\text { the list of persons who have leaked detailed } \\
\text { personal identification numbers. }\end{array}$ \\
\hline
\end{tabular}

In fact, it often appears that big data companies use website crawlers to crawl relevant information disclosed by the government, and then use the crawled data for secondary use. Big data companies' crawling of data is not a problem in itself, but the problem is that some big data companies have not done compliance with risk control. They did not clean and de-identify the crawled data, but instead used the property attributes of the data to directly resell the data to the demand side, which caused great harm to the data subjects. Some executives of Hangzhou big data company have been arrested some time ago. The original origin was to collect personal information crawled by the big data company, collect the location information of the lender to get the victim, and finally force the victim to jump to their deaths. ${ }^{22}$

\section{The LEGAL COMPLIANCE PATH IN THE INTEGRATED DEVELOPMENT OF GOVERNMENT AFFAIR INFORMATION RESOURCES}

According to the above, the sources of government information resources, such as unclear information, unclear information arrangement, unclear sharing of definitions, and overly rough open design, still exist. The author believes that internal data risk control compliance, standardization of the qualification approval of outsourcing organizations, and formulation of government data standards and policies are helpful to achieve legal compliance for government data integration.

\footnotetext{
21 See Article 5 of the Government Information Disclosure Regulations.

22 See Article 27 of the Government Information Disclosure Regulations.
}

23 See China News Week: Purging crawling company. URL:http://www.inewsweek.cn/survey/2019-10-21/7327.shtml, Last visit: October 28, 2019. 
of a data breach, and to formulate prosecution rules and increase the intensity of punishment to deter speculators.

Regarding the integration of government affairs data, the author believes that external supervision helps control the risk of data leakage, but the most fundamental control method lies in the relevant institutions' need to do a good job of internal risk control. For example, government affairs departments should establish and improve internal control systems, fully investigate links prone to government data leaks, and strengthen overall process management of network data security, timely rectify to eliminate major hidden dangers of data leakage and abuse, clearly stipulate the management responsibilities of posts and personnel in departments, strengthen the authority setting of government affairs data management, and form a management mechanism of mutual supervision and restriction. ${ }^{23}$

At the same time, government affairs departments should also improve the design of government data security management systems, establish classification and protection of government data, security risk assessment of government data, notification and disposal of government data security incidents, and external use reports of government data. It is also necessary to improve information security technology precautions to ensure that government data is not leaked during the collection, compilation, storage, use, sharing, and opening.

\section{B. Standardizing the Qualification Approval of Outsourcing Organizations to Avoid Data Leakage}

As can be seen from the above, government data is often entrusted to third-party agencies for processing, and even the infrastructure that carries the data, such as the government affairs cloud, is entrusted to external third parties for processing. The risk of data breaches is self-evident. Therefore, it is particularly important to standardize the qualification approval of outsourcing organizations.

The author believes that in order to regulate the qualification approval of outsourcing organizations, the threshold conditions for outsourcing organizations to participate in bidding should be defined first. That is, the outsourcing institution should conduct qualification review. For example, they should meet certain conditions in terms of name, place of business, registered capital, business scope, and secure registration of credit information systems, etc. At the same time, they should be submitted to the provincial Development and Reform Commission for approval at the same time. Second, the data collection and use of outsourced institutions should be documented. When major changes occur to the data, it is necessary to update the record. It is necessary to formulate the management rules for the record of outsourcing agencies, stipulate the main body of the record, etc. to implement the protection of data. Finally, it is necessary to implement the system for the first investigation of the person responsible for data breach, to clarify the accountability of the directly responsible persons in the event

24 See the "Telecommunications and Internet Industry Special Action Plan to Improve Network Data Security Protection Ability" and other documents.

\section{Formulating Standards and Policies for Government Affairs Data and Strengthening Data Supervision}

As mentioned above, there are uncertain legal concepts in the sharing of government affairs information resources, and there are no special regulatory documents for third-party sources of data. Many situations lead to a lot of ambiguities in the integration of government affairs data. Eliminating uncertain legal concepts through the legislative model is an important way to solve problems. However, if the resolution of each issue is regulated by the legislative model of the National People's Congress and its Standing Committee, it will consume huge judicial costs. At the same time, legislation is time-consuming and inefficient, and it is difficult to deal with new problems emerging in practice in a timely manner.

Therefore, the author suggests that for uncertain legal concepts in government affairs data sharing and third-party source specification documents for data, the problem can be solved by formulating standards and policies in the fields of government affairs data sharing. Specifically, it is led by the NDRC, the Ministry of Industry and Information Technology, and the Central Network Information Office, in conjunction with other departments, to jointly study and formulate government affairs data. It can also entrust subordinate institutions or corresponding technical departments to study and formulate. In fact, the government is also aware of the importance of the establishment of government affairs data integration standards, and requires that "the National Standards Committee and the management unit of the sharing platform should establish and improve government affairs information on the basis of existing standards for government affairs information resources standards for resource catalog classification, collection, sharing exchange, platform docking, network security protection, etc., forming a complete system of government affairs information resource sharing standards. ${ }^{24}$ Therefore, for the integration of government affairs data, formulating standards and policies for government data, and strengthening data Regulation may be effective.

\section{CONCLUSION}

The integration of government data involves sensitive information such as state secrets and personal information. If there is any problem with the huge government affairs data, it will have a great impact on national economic security and social public interests. Therefore, compliance research on government data is necessary. After research, it is found that there are currently unknown sources of government information resources, unorganized information arrangement, unclear sharing of definitions, and overly rough open design. The way to solve the problem of government data integration is to do a good job of internal data risk control compliance, standardize the qualification approval of outsourcing

25 See article 19 of "Interim measures for government affairs information resource sharing management". 
organizations, and formulate standards and policies for government data. However, due to the complexity of government data integration, this article only starts a discussion. It is expected that more experts and scholars in the practical and theoretical fields can do more in-depth research in the later period.

\section{REFERENCES}

[1] Ying Yan. Government Data Open Sharing and Construction of Shared Society: Measures and Exploration of Hainan [J]. Egovernment, 2019, (198): 82-90. (in Chinese)

[2] Xu Guanjun. On the Big Data of Government Affairs - Realistic Path of Government's Response to Reform [J]. Northern Economy and Trade. 2019, (8): 3-6. (in Chinese)

[3] Tie Jin, Liu Guanghao, Liu Yuan, Feng Xin. Sharing of Domestic Research Hotspots on Government Big Data [J]. China Management Informationization. 2019, (22): 116-117. (in Chinese)

[4] Jing Yaping. Exploration and Practice of Government Affairs Data Governance of Guizhou Province [J]. Software and Integrated Circuit, 2019, (8): 72-73. (in Chinese)

[5] Peng Jing, Zheng Yubo, Li Sisi. Constructing an Open and Shared System of Government Affair Datas [J]. Telecommunications Technology. 2019, (7): 85-88. (in Chinese)

[6] Zhou Hanhua. Research on Frontier Issues of Personal Information Protection [M]. Beijing: Law Press. China, 2008. (in Chinese)

[7] Zhou Ya, Li Dong, Wang Cui. Suggestions on the Construction and Development of Big Data in Beijing Government Affairs [J]. China Engineering Consulting. 2019, (8): 65-68. (in Chinese) 